\title{
Tobacco Usage among Males in Rural Tamil Nadu, India: A Cross-sectional Study
}

\author{
Kalaivani Annadurai, ${ }^{1}$ Geetha Mani, ${ }^{1}$ Raja Dhanasekaran. ${ }^{7}$
}

\begin{abstract}
Background: Knowing the prevalence of tobacco use and the socio-demographic profile of users might prove useful in further strengthening the information, education, communication and regulatory activities, thereby decreasing tobacco use. The objective was to study the prevalence and pattern of tobacco use among men aged 18 years and above in rural area of Tamil Nadu. Methods: A cross sectional study was performed among 714 males aged 18 years and above in Vadagarai village of Tamil Nadu during 2010 and interviewed with a pretested questionnaire. Systematic random sampling was used to select the participants. Results: Prevalence of smoking was found to be $36.7 \%$. Cigarette smoking was more common than beedi and smokeless tobacco. Conclusion: Strict enforcement of anti-tobacco legislation and awareness measures targeting ill-effects of tobacco can be intensified to reduce tobacco related morbidity and mortality.
\end{abstract}

Keywords: Tobacco, Prevalence, Smoking (Source: MeSH-NLM).

About the Author: Kalaivani Annadurai is a recently graduated public health physician and currently working as an assistant professor in the department of Community Medicine at Shri Sathya Sai Medical College and Research Institute.
Submission: Nov. 14, 2013 Acceptance: Jan. 29, 2014 Process: Peer-reviewed

\section{Introduction}

Tobacco is the most important preventable cause of death and disease among adults. According to World Health Organization (WHO), globally about six million people die prematurely every year due to tobacco use, mostly cigarette smoking. More important is the fact that this epidemic of disease and death caused by tobacco is increasing very rapidly. By 2030 it is expected to kill more than eight million people per year, if there is no proper action (WHO. Tobacco-facts sheet. Available from: http://www.who.int/mediacentre/factsheets/fs339/en/, updated 2013 Jul, cited 2014 Jan 28).

The tobacco epidemic is affecting mainly developing countries since $84 \%$ of world's smokers live in these countries. In low-income countries, nearly half of all men smoke daily and this trend seem to be increasing (World Bank. Economics of tobacco control. Available from: http://www.worldbank.org/tobacco/, updated 2013 Dec 18, cited 2013 Dec 20). Research has proved that secondhand smoke produces the same effect as first hand smoke including cardiovascular disease, lung cancer, and lung ailments such bronchitis and asthma attacks.' Smoking related mortality and morbidity can be prevented by reducing smoking prevalence.

In India, Tobacco consumption continues to grow at 2-3\% per annum. ${ }^{2}$ People in India consume smoking and smokeless tobacco in the form of cigarettes, non-cigarette items such as hand-rolled beedis, chewing paan etc. ${ }^{3}$ The prevalence of tobacco use among males has been high in all parts of India. The tobacco consumption is more in rural than in urban areas. In 2003, The Central Government passed 'The Cigarettes and

${ }^{1}$ Shri Sathya Sai Medical College \& Research Institute,Thiruporur,Tamilnadu, India
Other Tobacco Products Act' (COTPA) applicable to all tobacco products. ${ }^{4}$ But still, the prevalence of tobacco is a huge public health problem.

\section{Methods}

A cross-sectional study was performed among adult males aged 18 years and above in Vadagarai village in Thiruvallur district of Tamil Nadu.

The sample size was calculated on the basis of $35 \%$ prevalence rate of smoking in rural area according to NFHS-3 survey with an allowable error of $10 \%$, the sample size came to $714 .{ }^{5} \mathrm{Va}$ dagarai health sub center was chosen randomly from Naravarikuppam Block Primary Health Centre. In order to get 714 men aged 18 years and above, it was decided to survey 445 households in Vadagarai sub-center, with a total of 1581 households with population of 2539 men above 18 years. The households were sampled by systematic random sampling.

Respondents were interviewed using semi-structured questionnaire. The questionnaire for this study was developed based on Global Adult Tobacco Survey (Global Adult Tobacco Survey (CATS), Core Questionnaire with Optional Questions. Available from: http://www.who.int/tobacco/surveillance/guide/en/, updated 2013, cited 2013 Dec 13). It was translated into local language, pretested and standardized. It consisted of two parts of which Part I consists of questions related to socio-demographic profile and part II consist of questions regarding usage of smoking as well as smokeless tobacco.

Data entry was made in MS office Excel software in codes and analysis was done by SPSS software $®$. Descriptive statistical 
Table 1: Socio-demographic determinants of tobacco use $(n=714)$

\begin{tabular}{|c|c|c|c|c|}
\hline Socio-demographic variables & $\begin{array}{c}\text { Total } \\
\mathrm{N}=714(\%[95 \% \mathrm{Cl}])\end{array}$ & $\begin{array}{c}\text { Smoker } \\
\mathrm{N}=262(\%)\end{array}$ & $\begin{array}{l}\text { Non-Smoker } \\
\mathrm{N}=452(\%)\end{array}$ & $\mathrm{p}$ value \\
\hline \multicolumn{5}{|l|}{ Age } \\
\hline $\begin{array}{l}18-30 \\
31-40 \\
41-50 \\
51-60 \\
\text { More than } 60\end{array}$ & $\begin{array}{c}357(50.0 \%[46.33-53.67]) \\
112(15.68 \%[13.01-18.35]) \\
123(17.2 \%[14.43-19.97]) \\
93(13.02 \%[10.55-15.49]) \\
29(4.1 \%[2.65-5.55])\end{array}$ & $\begin{array}{l}123(34.45 \%) \\
34(30.36 \%) \\
46(37.4 \%) \\
43(46.24 \%) \\
16(55.2 \%)\end{array}$ & $\begin{array}{l}234(65.55 \%) \\
78(69.64 \%) \\
77(62.6 \%) \\
50(53.76 \%) \\
13(44.8 \%)\end{array}$ & 0.03 \\
\hline \multicolumn{5}{|l|}{ Marital status } \\
\hline $\begin{array}{l}\text { Single } \\
\text { Married } \\
\text { Widower/Divorced/separated }\end{array}$ & $\begin{array}{c}251(35.2 \%[31.7-38.7]) \\
415(58.10 \%[54.48-61.72]) \\
48(6.72 \%[4.88-8.56])\end{array}$ & $\begin{array}{l}95(37.85 \%) \\
141(33.98 \%) \\
26(54.17 \%)\end{array}$ & $\begin{array}{l}156(62.15 \%) \\
274(66.02 \%) \\
22(45.83 \%)\end{array}$ & 0.02 \\
\hline \multicolumn{5}{|l|}{ Education } \\
\hline $\begin{array}{l}\text { Illiterate } \\
\text { Literate }\end{array}$ & $\begin{array}{c}85(11.91 \%[9.53-14.29]) \\
629(88.09 \%[85.71-90.47])\end{array}$ & $\begin{array}{l}42(49.40 \%) \\
220(35.00 \%)\end{array}$ & $\begin{array}{l}43(50.60 \%) \\
409(65.00 \%)\end{array}$ & 0.01 \\
\hline \multicolumn{5}{|l|}{ occupation } \\
\hline $\begin{array}{l}\text { Unemployed/student } \\
\text { Daily wagers } \\
\text { Monthly wagers } \\
\text { Semiprofessional/Professional } \\
\text { Retired/old age dependent }\end{array}$ & $\begin{array}{c}39(5.46 \%[3.79-7.1]) \\
288(40.33 \%[36.73-43.93]) \\
352(49.3 \%[45.63-52.97]) \\
13(1.82 \%[0.84-2.8]) \\
22(3.08 \%[1.81-4.35])\end{array}$ & $\begin{array}{c}8(20.5 \%) \\
127(44.1 \%) \\
118(33.52 \%) \\
1(7.7 \%) \\
8(36.4 \%)\end{array}$ & $\begin{array}{l}31(79.5 \%) \\
161(55.9 \%) \\
234(66.48 \%) \\
12(92.3 \%) \\
14(63.6 \%)\end{array}$ & 0.002 \\
\hline \multicolumn{5}{|l|}{ Socio-economic status ${ }^{18}$} \\
\hline $\begin{array}{l}3653 \text { and above(Class-I) } \\
1827-3652 \text { (Class-II) } \\
1096-1826 \text { (Class-III) } \\
548-1095(\text { Class-IV) } \\
<547 \text { (Class-V) }\end{array}$ & $\begin{array}{c}13(1.82 \%[0.84-2.8]) \\
87(12.18 \%[9.78-14.58]) \\
160(22.4 \%[19.34-25.46]) \\
350(49.01 \%[43.34-52.68]) \\
104(14.56 \%[11.97-17.15])\end{array}$ & $\begin{array}{l}6(46.2 \%) \\
26(29.9 \%) \\
53(33.1 \%) \\
137(39.1 \%) \\
40(38.5 \%)\end{array}$ & $\begin{array}{l}7(53.8 \%) \\
61(70.1 \%) \\
107(66.9 \%) \\
213(60.9 \%) \\
64(61.5 \%)\end{array}$ & 0.38 \\
\hline
\end{tabular}

analysis, which included frequency, mean and percentages, was used to characterize the data. 95\% Confidence Intervals ( $95 \% \mathrm{Cl})$ were calculated. Association with the factors was tested for significance using chi-square test and $p<0.05$ was considered statistically significant.

\section{Results}

The mean age of the sample population was 35.34 years \pm 13.98 with range of $18-85$ years. Half of them were between 18-30 years. Most of them were Hindus ( $82.5 \%$ ). Literacy rate of the sample population seems to be high ( $88.09 \%$ ). $49.01 \%$ of the participants were from upper-middle class socio-economic group and $76.05 \%$ were unskilled, semi-skilled and skilled laborers. (Table 1)

Smoking status was found to be statistically significant with age, marital status, education and occupation. But it was not found to be significantly associated with socio-economic status (Table 1).

Table 2 depicts the prevalence of smoking in men in the study population ( $95 \% \mathrm{Cl}=33.2$ to 40.4 ), $36.7 \%$ of the study group were current smokers. Among smokers the majority of them were using cigarettes $(64.5 \%)(95 \% \mathrm{Cl}=58.71$ to 70.29$)$ and $24 \%(95 \% \mathrm{Cl}=18.83$ to 29.17$)$ were using beedi. $2.7 \%$ were exsmokers and $60.6 \%$ were non smokers. Analysis of the use of smokeless tobacco shows $28.4 \%(95 \% \mathrm{Cl}=25.09$ to 31.71$)$ of the study population $(n=714)$ use smokeless tobacco products. Combined users of both smoking and smokeless tobacco totaled $33(12.6 \%)(95 \% \mathrm{Cl}=10.17$ to 15.03$)$ among the study population.

Analysis of the number of smoking days in the past 30 days shows that the majority of the smoking population ( $80.2 \%$ ) ( $95 \% \mathrm{Cl}=76.16$ to 85.68$)$ were smoking for more than two thirds of the months. The mean duration of smoking was 15.93 years and the mean number of cigarettes or beedis smoked per day was 8.5 among smokers (Table 2).

\section{Discussion}

of the study population of 714 men aged 18 years and above in Vadagarai village of Thiruvallur district, Tamil Nadu, the prevalence of smoking was $36.7 \%$. Similar findings were obtained from NFHS - 3 and Kaur P., et al. ${ }^{5,6}$ But it was found to be lower than the findings from Vivek Gupta et al where it was $47.9 \%$ and higher than Rani $\mathrm{M}$ et al, and Daniel $\mathrm{AB}$ et al where it was found to be $29.3 \%$ and $17.5 \%$ respectively. ${ }^{7,8,9}$ The prevalence in our study $(36.7 \%)$ was found to be higher than in the United States (21.6\%-Centers for Disease Control) ${ }^{10}$ and lower than in China (52.9\%- Harris et al). ${ }^{11}$

Smokeless tobacco users were $28.4 \%$ and this was similar to Rani M., et al (28.1\%) and higher than that of $6.8 \%$ which was reported in Vivek Gupta et al but lower than $36 \%$ which was observed from NFHS-3 findings. 5,7,8 Combined users of both smokeless and smoking tobacco were found to be $12.6 \%$ in the current study. This was higher than that of $2.1 \%$ reported from Vivek Gupta et al and lower than that of $30 \%$ which was 
Table 2: Smoking tobacco usage pattern (n-262)

\begin{tabular}{|c|c|}
\hline Category & $\begin{array}{c}\text { Frequencies } \\
\mathrm{N}=262(\%[95 \% \mathrm{Cl}])\end{array}$ \\
\hline \multicolumn{2}{|l|}{ Type of smoking } \\
\hline Cigarette usage & $169(64.5 \%[58.71-70.29])$ \\
\hline Beedi usage & $63(24.0 \%$ [18.83-29.17]) \\
\hline Both cigarette and beedi & $30(11.5 \%[7.64-15.36])$ \\
\hline \multicolumn{2}{|c|}{ Number of Days of smoking in the past Month } \\
\hline$\leq 10$ days & $19(7.25 \%[4.11-10.39])$ \\
\hline 11-20 days & $31(11.83 \%[7.92-15.74])$ \\
\hline 21-30 days & $212(80.92 \%[76.16-85.68])$ \\
\hline \multicolumn{2}{|l|}{ Duration of smoking } \\
\hline$\leq 1$ year & $23(8.8 \%[5.37-12.23])$ \\
\hline 2-10 years & $98(37.4 \%[31.54-43.26])$ \\
\hline $11-20$ years & $52(19.8 \%[14.97-24.63])$ \\
\hline 21-30 years & $47(18.0 \%[13.35-22.65])$ \\
\hline $31-40$ years & $22(8.4 \%[5.04-11.76])$ \\
\hline 41 years and above & $20(7.6 \%[4.39-10.81])$ \\
\hline \multicolumn{2}{|c|}{ Number of cigarettes or beedis used per day } \\
\hline$\leq 1$ & $81(31.0 \%[25.4-36.6])$ \\
\hline $2-5$ & $53(20.2 \%[15.34-25.06])$ \\
\hline $6-10$ & $53(20.2 \%[15.34-25.06])$ \\
\hline $11-20$ & $32(12.2 \%[8.24-16.16])$ \\
\hline$\geq 21$ & $43(16.4 \%[11.92-20.88])$ \\
\hline
\end{tabular}

observed from Rani M., et al.7.8

In the current study, prevalence of smoking was $36.7 \%$ and among them $80.92 \%$ were smoking for more than two thirds of the month. This was similar to findings from Harris et al. This shows the depth of the problem. Around $64.5 \%$ were using $\mathrm{ci}$ garettes and $24.0 \%$ were using beedi. This was in contrast with Chaudhry $\mathrm{K}$ et al report that beedi usage is more common that cigarette smoking in rural areas. ${ }^{12}$

According to Rani $\mathrm{M}$ et al, tobacco usage increases with increasing age..$^{8}$ In our study population there was a biphasic trend in smoking pattern i.e., the prevalence of smoking was $34.45 \%$ between $18-30$ years, decreased with $30.36 \%$ in between $31-40$ years and increased to $55.2 \%$ for those with more than 60 years of age i.e., prevalence was more among younger and older age groups.

Prevalence of smoking was more common in illiterates than well-educated. This report was similar to the findings from NFHS-3, Rani M et al, Harris et al and Narayan et al., $, 5,8,11,13$ In our study population there was no significant association between smoking and socioeconomic status. Smoking status was found to be significantly associated with age group, education, marital status and occupation. But beedi usage was more common in lower socio economic people. Similar findings were seen in the study conducted by Ram B singh et al. ${ }^{14}$

\section{Conclusion}

The study concludes that the prevalence of smoking was higher than the Indian national average. Therefore, preventive steps like lifestyle modifications, communication, fiscal measures and further more strong enforcement of the COTPA act 2003 will be needed to decrease the prevalence further. 


\section{Short Communication}

\section{References}

1. U.S. Department of Health and Human Services. The Health Consequences of Involuntary Exposure to Tobacco Smoke: A Report of the Surgeon Ceneral. Atlanta, CA: U.S. Department of Health and Human Services, Centers for Disease Control and Prevention, Coordinating Center for Health Promotion, National Center for Chronic Disease Prevention and Health Promotion, Office on Smoking and Health, 2006.

2. Tarveen Jandoo, Ravi M. Tobacco Control in India: Present Scenario and Challenges Ahead. Asian Pac J Cancer Prev. 2008;9(4):805-10.

3. Bhonsle RB, Murti PR, Gupta PC. Tobacco habits in India. In: Gupta PC, Hamner J III, Murti P (eds). Control of tobacco-related cancers and other diseases. Proceedings of an International Symposium, 15.19 January 1990; Mumbai: TIFR, Oxford University Press; 1992:25.46.

4. Government of India. The Cigarettes and Other Tobacco Products (Prohibition of Advertisement and Regulation of Trade and Commerce, Production, Supply and Distribution) Act, 2003, and rules framed there under.

5. International Institute for Population Sciences (IIPS) and Macro International. 2007. National Family Health Survey (NFHS-3), 2005-06: India: Volume I. 6. Kaur P, Rao SR, Radhakrishnan E, Ramachandran R, Venkatachalam R, Gupte MD. High prevalence of tobacco use, alcohol use and overweight in a rural population of Tamil Nadu, India. J Postgrad Med. 2011; 57(1):9-15

7. Vivek Gupta, Kapil Yadav, Anand K. Patterns of tobacco use across Rural, Urban, and Urban-Slum Populations in a North Indian Community. Indian J Community Med. 2010;35(2):245-51.
8. Rani M, Bonu S, Jha P, Nguyen SN, Jamjoum L. Tobacco use in India: prevalence and predictors of smoking and chewing in a national cross sectional household survey. Tob Control. 2003;12(4):1-8

9. Daniel AB, Nagaraj K, Kamath R. Prevalence and determinants of tobacco use in a highly literate rural community in southern India. Natl Med J India. 2008;21(4):163-5.

10. Centers for Disease Control, current cigarette smoking among adultsUnited States, 2011. MMWR. 2012;61:889-94.

11. Harris M, Buerhaus P, Needleman J. Prevalence of Smoking in China in 2010. N Engl J Med. 2011:364(25):2469-70.

12. Chaudhry K, Prabhakar AK, Prabhakaran PS, Prasad A, Singh K, Singh A. Prevalence of tobacco use in Karnataka and Uttar Pradesh in India. Final report of the study by the Indian Council of Medical Research and the WHO South East Asian Regional Office, New Delhi; 2001.

13. Narayan K.M, Chadha, R. L. Hanson, R. Tandon, S. Shekhawat, R. J. Fernandes, and N. Gopinath. Prevalence and patterns of smoking in Delhi: cross sectional study. BMJ. 1996;312(7046):1576-9

14. Ram B Singh Surendra Singh, Pronobesh Chattopadhya, Kalpana Singh, Vijender Singh, Shallendra K Kulshrestha et al. Tobacco consumption in relation to causes of death in an urban population of north India. Int J Chron Obstruct Pulmon Dis. 2007;2(2):177-85.

15. Suryakantha AH. Demography. Community Medicine with recent advances. 2nd edition. Bengaluru, India: Jaypee Brothers Medical Publishers(P) Ltd; 2010.p.591.

\section{Acknowledgments}

I sincerely thank Prof. Dr. Ilango, Director, Dr. Nagarani, Associate professor and Dr. Anantharaman, Assistant Professor, Institute of Community medicine, Madras Medical College for their guidance and support.

Conflict of Interest Statement at Funding

The authors have no funding, financial relationships or conflicts of interest to disclose.

Cite as:

Annadurai K, Mani C, Dhanasekaran R. Tobacco Usage among Males in Rural Tamil Nadu, India: A Cross-sectional Study. Int J Med Students. 2014;2(1):18-21. 